\title{
A New Alternative to Produce Gibberellic Acid by Solid State Fermentation
}

\author{
Cristine Rodrigues, Luciana Porto de Souza Vandenberghe, Juliana Teodoro, Juliana \\ Fraron Oss, Ashok Pandey and Carlos Ricardo Soccol* \\ Departamento de Engenharia de Bioprocessos e Biotecnologia; Universidade Federal do Paraná; Curitiba - PR - \\ Brasil
}

\begin{abstract}
Gibberellic acid $\left(\mathrm{GA}_{3}\right)$ is an important hormone, which controls plant's growth and development. Solid State Fermentation (SSF) allows the use of agro-industrial residues reducing the production costs. The screening of strains (four of Gibberella fujikuoroi and one of Fusarium moniliforme) and substrates (citric pulp, soy bran, sugarcane bagasse, soy husk, cassava bagasse and coffee husk) and inoculum preparation study were conducted in order to evaluate the best conditions to produce $\mathrm{GA}_{3}$ by SSF. Fermentation assays were carried out in erlenmeyers flasks at $29^{\circ} \mathrm{C}$, with initial moisture of 75-80\%. Different medium for inoculum production were tested in relation to cells viability and $G A_{3}$ production by SSF. F. moniliforme LPB 03 and citric pulp were chosen for GA $A_{3}$ production. The best medium for inoculum production was citric pulp extract supplemented with sucrose. GA 3 production by SSF reached $5.9 \mathrm{~g} / \mathrm{kg}$ of dry CP after 3 days of fermentation.
\end{abstract}

Key words: gibberellic acid, Fusarium moniliforme, solid state fermentation, inoculum, agro-industrial residues

\section{INTRODUCTION}

Gibberellic acid $\left(\mathrm{GA}_{3}\right)$ is an important member of the gibberellins family and acts as a natural plant growth hormone, controlling many development processes, which is gaining great attention all over the world due to its effective use in agriculture, nurseries, tissue culture, tea gardens, etc. (Davies, 2004; Shukla et al., 2005). The cost of $\mathrm{GA}_{3}$ has restricted its use to preclude application for plant growth promotion, except for certain high value plants. Reduction in its production costs could lead to wider applications for a variety of crops (Kumar and Lonsane, 1989; Tudzynski, 1999; Linnemannstons et al., 2002).
Industrially $\mathrm{GA}_{3}$ is produced by submerged fermentation (SmF) using the ascomycetous fungus Gibberella fujikuroi, renamed Fusarium fujikuroi (O'Donnell et al., 1998). The cost of $\mathrm{GA}_{3}$ production using $\mathrm{SmF}$ is very high, mainly due to extremely low yield and expensive downstream processing.

Therefore in recent years the possibility of using solid state fermentation (SSF) has attracted a great deal of attention (Machado et al., 2004; Corona et al., 2005). In fact, the SSF technique has shown a number of economic advantages over $\mathrm{SmF}$ process in the production of microbial biomass and metabolites and the valorization of agro-industrial by-products (Pandey et al., 2001; Soccol and Vandenberghe, 2003; Soccol et al., 2006). Various

\footnotetext{
*Author for correspondence: soccol@ufpr.br
} 
processes of $\mathrm{GA}_{3}$ production using SSF have been studied (see Table 1).

The main objective of the present investigation was select strains and substrates and study the inoculum preparation for $\mathrm{GA}_{3}$ production by $\mathrm{SSF}$ using agro-industrial residues.

Table 1 - Different strategies $\mathrm{GA}_{3}$ production in SSF using waste and/or by products

\begin{tabular}{|c|c|c|c|c|}
\hline Substrate/ Support & Estrategy & Bioreactor & Production & References \\
\hline Glucose and Glicina & 20.1 .0 .08 & Stirred fermentor $(6 \mathrm{~L})$ & $520 \mathrm{mg} / \mathrm{L}$ & $\begin{array}{l}\text { Hollmann et al., } \\
1995\end{array}$ \\
\hline Wheat meal & Fed-batch operation & $\begin{array}{l}\text { Pilot-scale reactor } \\
\qquad(50 \mathrm{~L})\end{array}$ & $3 \mathrm{~g} / \mathrm{kg}$ & Bandelier et al., 1997 \\
\hline $\begin{array}{l}\text { Glucose and rice } \\
\text { meal }\end{array}$ & & $\begin{array}{l}\text { erlenmeyer flasks } \\
\quad(500 \mathrm{~mL})\end{array}$ & $2,862 \mathrm{~g} / \mathrm{L}$ & $\begin{array}{l}\text { Escamilla et al., } \\
2000\end{array}$ \\
\hline $\begin{array}{l}\text { Coffee husk and } \\
\text { cassava bagasse }\end{array}$ & $\begin{array}{l}\text { Optimization of physical } \\
\text { and chemical conditions }\end{array}$ & $\begin{array}{l}\text { erlenmeyer flasks } \\
(250 \mathrm{~mL})\end{array}$ & $492,5 \mathrm{mg} / \mathrm{kg}$ & Machado et al., 2002 \\
\hline $\begin{array}{l}\text { Glucose and rice } \\
\text { meal }\end{array}$ & & $\begin{array}{l}\text { erlenmeyer flasks } \\
(250 \mathrm{~mL})\end{array}$ & $1 \mathrm{~g} / \mathrm{L}$ & Shukla et al., 2005 \\
\hline $\begin{array}{l}\text { Wheat meal and } \\
\text { soluble starch }\end{array}$ & $\begin{array}{l}\text { Optimization of physical } \\
\text { chemical conditions }\end{array}$ & Glass columns & $4.5-5 \mathrm{~g} / \mathrm{kg}$ dry basis & Corona et al., 2005 \\
\hline
\end{tabular}

\section{MATERIALS AND METHODS}

\section{Microorganism}

Strains of Gibberella fujikuroi LPB 02, LPB 05, LPB 06, LPB Bca and Fusarium moniliforme LPB 03, were conserved in PDA (Potato Dextrose Agar) slants, where the microorganism was cultured. These strains were incubated at $28^{\circ} \mathrm{C}$ for six days and kept at $4^{\circ} \mathrm{C}$ for up to two months.

\section{Substrates}

Six agro-industrial residues were used as substrate in this study: citric pulp (CP), soy bran (SB), sugarcane bagasse (SCB), soy husk ( $\mathrm{SH})$, cassava bagasse (CB) and coffee husk (CH). These substrates were previously dried, triturated in a records mill and bolted to get a particle size between 0.8 and $2 \mathrm{~mm}$.

$\mathrm{CH}$ was pre-treated with an alkaline solution $\left(\mathrm{KOH} 0,25 \%, 100^{\circ} \mathrm{C}\right.$ for $\left.45 \mathrm{~min}\right)$ in order to eliminate toxic substances naturally present in the $\mathrm{CH}$ (Machado et al., 2002).

\section{Solid State Fermentation (SSF)}

Substrates were impregnated with the nutritive solution containing $\mathrm{FeSO}_{4} .7 \mathrm{H}_{2} \mathrm{O}$ and $\left(\mathrm{NH}_{4}\right)_{2} \mathrm{SO}_{4}$, in order to have an initial moisture content of 75$80 \%$. The $\mathrm{pH}$ was adjusted to $5.0-5.5$ and the support was then inoculated $(10 \%-20 \% \mathrm{v} / \mathrm{w})$. After homogenization, the inoculated support was transferred to $250 \mathrm{~mL}$ erlenmeyer flasks. Flasks were incubated for 7 days at $29^{\circ} \mathrm{C}$.

The screening of strains and substrates was conducted using an experimental design (six factor simplex-lattice design). The mixture of six agroindustrial residues (previously described) in a 1:1 ratio was studied for the five strains (Table 2). The inoculum used in this step $(15 \% \mathrm{v} / \mathrm{w})$ was obtained by growth in Czapek broth medium for seven days. 
Table 2 - Six factor simplex-lattice design for individual tests using different residues as substrates

\begin{tabular}{cccccccccccc}
\hline Assay & CP & CB & SB & SH & CH & SCB & $\begin{array}{c}\text { LPB 02 } \\
\text { strain }\end{array}$ & $\begin{array}{c}\text { LPB 03 } \\
\text { strain }\end{array}$ & $\begin{array}{c}\text { LPB 05 } \\
\text { strain }\end{array}$ & $\begin{array}{c}\text { LPB 06 } \\
\text { strain }^{*}\end{array}$ & $\begin{array}{c}\text { LPB BCA } \\
\text { strain }^{*}\end{array}$ \\
\hline $\mathbf{1}$ & 1 & 0 & 0 & 0 & 0 & 0 & 3.9 & 5.7 & 3.8 & 3.1 & 3.5 \\
$\mathbf{2}$ & 0 & 1 & 0 & 0 & 0 & 0 & 0.5 & 0.5 & 0.3 & 1.1 & 0.8 \\
$\mathbf{3}$ & 0 & 0 & 1 & 0 & 0 & 0 & 0.0 & 3.8 & 0.0 & 0.0 & 3.4 \\
$\mathbf{4}$ & 0 & 0 & 0 & 1 & 0 & 0 & 3.7 & 2.8 & 1.8 & 1.8 & 2.8 \\
$\mathbf{5}$ & 0 & 0 & 0 & 0 & 1 & 0 & 3.1 & 0.8 & 2.9 & 2.8 & 3.3 \\
$\mathbf{6}$ & 0 & 0 & 0 & 0 & 0 & 1 & 0.7 & 1.0 & 2.4 & 1.5 & 0.9 \\
$\mathbf{7}$ & $1 / 2$ & $1 / 2$ & 0 & 0 & 0 & 0 & 1.5 & 2.9 & 0.3 & 1.3 & 1.9 \\
$\mathbf{8}$ & $1 / 2$ & 0 & $1 / 2$ & 0 & 0 & 0 & 4.0 & 1.0 & 1.9 & 0.0 & 0.0 \\
$\mathbf{9}$ & $1 / 2$ & 0 & 0 & $1 / 2$ & 0 & 0 & 3.9 & 5.0 & 3.7 & 3.0 & 3.0 \\
$\mathbf{1 0}$ & $1 / 2$ & 0 & 0 & 0 & $1 / 2$ & 0 & 2.4 & 4.3 & 1.1 & 3.1 & 4.0 \\
$\mathbf{1 1}$ & $1 / 2$ & 0 & 0 & 0 & 0 & $1 / 2$ & 2.0 & 1.5 & 0.0 & 1.1 & 0.7 \\
$\mathbf{1 2}$ & 0 & $1 / 2$ & $1 / 2$ & 0 & 0 & 0 & 1.1 & 0.0 & 0.0 & 0.0 & 0.0 \\
$\mathbf{1 3}$ & 0 & $1 / 2$ & 0 & $1 / 2$ & 0 & 0 & 3.5 & 3.1 & 0.5 & 0.0 & 1.5 \\
$\mathbf{1 4}$ & 0 & $1 / 2$ & 0 & 0 & $1 / 2$ & 0 & 1.4 & 2.2 & 2.2 & 2.2 & 3.0 \\
$\mathbf{1 5}$ & 0 & $1 / 2$ & 0 & 0 & 0 & $1 / 2$ & 0.7 & 1.3 & 2.2 & 0.9 & 1.1 \\
$\mathbf{1 6}$ & 0 & 0 & $1 / 2$ & $1 / 2$ & 0 & 0 & 1.2 & 1.1 & 2.6 & 4.7 & 3.2 \\
$\mathbf{1 7}$ & 0 & 0 & $1 / 2$ & 0 & $1 / 2$ & 0 & 1.2 & 0.9 & 3.6 & 4.3 & 3.5 \\
$\mathbf{1 8}$ & 0 & 0 & $1 / 2$ & 0 & 0 & $1 / 2$ & 1.1 & 0.8 & 1.5 & 0.0 & 0.8 \\
$\mathbf{1 9}$ & 0 & 0 & 0 & $1 / 2$ & $1 / 2$ & 0 & 3.4 & 3.6 & 3.1 & 1.3 & 2.6 \\
$\mathbf{2 0}$ & 0 & 0 & 0 & $1 / 2$ & 0 & $1 / 2$ & 0.0 & 0.0 & 2.2 & 2.3 & 3.0 \\
$\mathbf{2 1}$ & 0 & 0 & 0 & 0 & $1 / 2$ & $1 / 2$ & 2.3 & 2.2 & 1.1 & 0.4 & 1.7 \\
\hline
\end{tabular}

citric pulp (CP), soy bran (SB), sugarcane bagasse (SCB), soy husk (SH), cassava bagasse (CB) and coffee husk (CH) . * Production of GA3: $\mathrm{g}$ of GA3/kg of dry waste.

\section{Development of inoculum production}

Different medium for inoculum production (pellets with posterior growth in Czapek broth medium, PDA medium, Czapek broth medium, citric pulp extract) were tested in relation to cells viability of the selected strain and $\mathrm{GA}_{3}$ production by SSF.

\section{PDA Medium}

The mycelia of the selected fungus was produced in $125 \mathrm{~mL}$ erlenmeyer flasks containing $30 \mathrm{~mL}$ PDA medium from the stock culture and incubated at $28^{\circ} \mathrm{C}$ for seven days. The mycelia suspension was recovered by scraping using $30 \mathrm{~mL}$ of a $0.01 \%$ Tween 80 solution. The obtained suspension was then stored at $4^{\circ} \mathrm{C}$ for up to seven days.

\section{Pellets growth with posterior growth in czapek broth medium}

The mycelia of the selected fungus was produced in a petri dish containing $20 \mathrm{~mL}$ PDA medium and incubated at $28^{\circ} \mathrm{C}$ for seven days. Five discs of 6 $\mathrm{mm}$ of the solid culture was inoculated in $125 \mathrm{~mL}$ erlenmeyer flasks containing $30 \mathrm{~mL}$ of Czapek broth medium and incubated at $30^{\circ} \mathrm{C}$ and $120 \mathrm{rpm}$ for seven days.

\section{Czapek broth medium}

The mycelia of the selected fungus was produced in PDA slants that were incubated at $28^{\circ} \mathrm{C}$ for seven days. The mycelia suspension was produced by scraping using a platinum strep for inoculation in $125 \mathrm{~mL}$ erlenmeyer flasks containing $30 \mathrm{~mL}$ of Czapek broth medium, which were incubated at $30^{\circ} \mathrm{C}$ and $120 \mathrm{rpm}$ for seven days.

\section{CP extract}

$\mathrm{CP}$ extract was produced using $5 \mathrm{~g}$ of $\mathrm{CP}$ (previously dried and triturated in a record mill and bolted to get a particle size smaller than 0.8 $\mathrm{mm}$ ), with the addition of $50 \mathrm{~mL}$ of water. The mixture was boiled during $30 \mathrm{~min}$ and then filtrated.

The media, which was in $125 \mathrm{~mL}$ erlenmeyer flasks containing CP extract (1:10 in water), was inoculated by scraping the platinum strep over the medium from the stock culture. Flasks were incubated at $30^{\circ} \mathrm{C}$ and $120 \mathrm{rpm}$ for 7 days.

\section{Cells Viability}

Each strain was inoculated in a $125 \mathrm{ml}$ erlenmeyer flask containing $20 \mathrm{ml}$ of the studied medium. Every 24 hours one erlenmeyer flask was withdrawn. $100 \mu \mathrm{L}$ of the mycelia suspension were 
transferred to petri dishes containing PDA medium. Successive dilutions were made in order to have between 30 to 300 colonies/Petri dish. Colonies were then counted and the viability was calculated (Banwart, 1982).

\section{Analytical Methods}

$15 \mathrm{~g}$ of the fermented and homogenized material was added of $45 \mathrm{~mL}$ phosphate buffer $(\mathrm{pH} 8.0)$ and mixed for 20 minutes. $30 \mathrm{~mL}$ of the filtered, which was previously purified according to the Holbrook method (Holbrook et al., 1961), was acidified with $\mathrm{HCl} 30 \%$ in a $100 \mathrm{~mL}$ volumetric flasks containing $10 \mathrm{~mL}$ absolute ethanol. Samples were analyzed in a spectrophotometer, after 75 minutes at $20^{\circ} \mathrm{C}$, where $\mathrm{GA}_{3}$ was measured at 254 nm.

\section{RESULTS AND DISCUSSION}

\section{Screening of Strains and Substrates for $\mathbf{G A}_{3}$ Production}

In this study the selection of a $\mathrm{GA}_{3}$ productive strain and a suitable substrate or a mixture of substrates was carried out. The production of $\mathrm{GA}_{3}$ by solid-state fermentation was then determined.

Table 2 presents the results of $\mathrm{GA}_{3}$ production with the five studied strains using the combinations of the six substrates. Concerning the substrates, $\mathrm{CP}$ presented very good levels of $\mathrm{GA}_{3}$ production with all strains (Table 2). Regarding the strains, the best $\mathrm{GA}_{3}$ accumulation was obtained by $F$. moniliforme LPB $03(5.7 \mathrm{~g}$ of
$\mathrm{GA}_{3} / \mathrm{kg}$ of $\mathrm{CP}$ ) followed by $G$. fujikuroi LPB 06 (4.7g of $\mathrm{GA}_{3} / \mathrm{kg}$ of $\mathrm{SB}: \mathrm{CH}$ ) which were selected for the next steps of the study.

Analyzing the results obtained for the substrates and their mixtures, the best combination was $\mathrm{CP}$ and $\mathrm{SH}$ with has shown productions over $3.0 \mathrm{~g}$ $\mathrm{GA}_{3} / \mathrm{kg}$ of dry substrate for all strains. Contrarily, the combination of $\mathrm{CB}$ : SB did not present any production except when the strain LPB02, that produced only $1.1 \mathrm{~g}$ of $\mathrm{GA}_{3} / \mathrm{kg}$ of dry $\mathrm{CB}: \mathrm{SB}$. If used separately, the substrates $\mathrm{CB}$ and SCB have not showed significant results of production under the conditions studied.

The production of gibberellins starts when nitrogen is depleted and continues when a sufficient carbon concentration is available in the substrate (Escamilla et al., 2000). In this way, substrates must provide an initial mycelia growth in a nitrogen-limited balanced medium, the beginning of $\mathrm{GA}_{3}$ production after nitrogen exhaustion and an extended metabolite production in the presence of sufficiently available carbon substrate. In fact, the best production was reached using CP. This fact can be due to the presence of $5 \%$ and $19 \%$ of proteins and carbohydrates, respectively (Rodrigues, 2006) and, consequently, a high $\mathrm{C} / \mathrm{N}$ ratio.

$\mathrm{SB}, \mathrm{SH}$ and $\mathrm{CH}$ have a large amount of $\mathrm{N}$ in its formulation which gives them a very low relationship C/N (Kagawa, 1995; Machado et al., 2001) compared to CB and CP (Table 3). Changes in the $\mathrm{C}: \mathrm{N}$ ratio were determinant to find the best strain and substrate for $\mathrm{GA}_{3}$ production. So this study aimed to guide the following steps to optimize this process.

Table 3 - Protein and carbohydrate composition of the substrates.

\begin{tabular}{lcccccc}
\hline & CP* & CB* & SB $^{*}$ & SH $^{*}$ & CH$^{*}$ & SCB* \\
\hline Proteins & $5 \%$ & $0.24 \%$ & $48 \%$ & $13-14(\%)$ & $10.9 \%$ & $0-0.3 \%$ \\
Carbohydrates & $19 \%$ & $67 \%$ & - & - & $17.4 \%$ & $39.7-49 \%$ \\
Reference & Rodrigues, & Vandenberghe et & IMCOPA, & POLINUTRI, & Souza et al., & Castro et \\
& 2006 & al., 2000 & 2007 & 2007 & 2001 & al., 2008 \\
\hline
\end{tabular}

* citric pulp (CP), soy bran (SB), sugarcane bagasse (SCB), soy husk (SH), cassava bagasse (CB) and coffee husk (CH).

\section{Development of inoculum production}

The development of a biotechnological process passes through different important steps. One of them is the inoculum production, which generally involves the study of cells viability, the optimization of medium composition and the genetic amelioration of the strain. Some details of the medium used for cell reproduction (inoculum production) are sometimes not really verified. However, a very significant gain in productivity can be reached with these procedures.

Tests were performed so as to choose the best medium for inoculum production using the selected strain $F$. moniliforme LPB 03 . Fig 1 
shows the kinetics of viability according to the different methods of inoculum production. Czapek broth proportioned the highest viable cells count reaching up to $10^{9}$ colonies / $\mathrm{mL}$ of medium in the $7^{\text {th }}$ day of growth.

The viability of each method of inoculum production was tested with respect to $\mathrm{GA}_{3}$ production by SSF using $\mathrm{CP}$ as substrate. The production of $\mathrm{GA}_{3}$ was determined in the $4^{\text {th }}$ and $7^{\text {th }}$ days using with 10,15 and $20 \%(\mathrm{v} / \mathrm{w})$ of inoculum. Good results of $\mathrm{GA}_{3}$ were attained with all different methodologies of inoculum production. The best results were obtained using $15 \%(\mathrm{v} / \mathrm{w})$ of the inoculum grown in Czapek medium $(5.3 \mathrm{~g} / \mathrm{kg}$ of $\mathrm{CP})$ in the $4^{\text {th }}$ day of fermentation. The methodologies of pellets formation, with subsequent growth in Czapek medium, and the PDA medium, have shown good results using both $10 \%$ of inoculum rate $(3.10 \mathrm{~g} / \mathrm{kg}$ of $\mathrm{CP}$ and $2.40 \mathrm{~g} / \mathrm{kg}$ of $\mathrm{CP}$, respectively), Although these two methodologies can not be economically justified at industrial scale. PDA and Czapeck are expensive mediums. The inoculum which was grown in $\mathrm{CP}$ extract, though less rich in nutrients, also showed good results in the $4^{\text {th }}$ day of fermentation (3.01 g / kg of CP) (Table 3). However, $20 \%$ of inoculum rate was used in this case, that could be seen as a limiting factor for its industrial application.

Table $3-\mathrm{GA}_{3}$ production in SSF using different media for inoculum growth.

\begin{tabular}{|c|c|c|c|c|c|c|}
\hline \multirow{2}{*}{ Inoculum (inoculum rate) } & \multicolumn{3}{|c|}{$4^{\text {th }}$ day of fermentation ${ }^{*}$} & \multicolumn{3}{|c|}{$7^{\text {th }}$ day of fermentation ${ }^{*}$} \\
\hline & $10 \%$ & $15 \%$ & $20 \%$ & $10 \%$ & $15 \%$ & $20 \%$ \\
\hline Czapek medium & 2.42 & 5.30 & 1.50 & 3.10 & 0.60 & 1.67 \\
\hline PDA medium & 2.40 & 1.86 & 1.13 & 3.97 & 3.00 & 3.84 \\
\hline $\begin{array}{l}\text { Pellets growth with posterior } \\
\text { growth in Czapek medium }\end{array}$ & 3.10 & 2.92 & 3.19 & 3.37 & 1.13 & 0.7 \\
\hline $\mathrm{CP}$ extract & 0.83 & 1.77 & 3.01 & 2.14 & 1.46 & 1.66 \\
\hline
\end{tabular}

${ }^{*}$ Production defined in $\mathrm{g}$ of $\mathrm{GA}_{3} / \mathrm{kg}$ of $\mathrm{CP}$.

Fig 1 shows the number of viable cells of the strain $F$. moniliforme LPB 03 cultivated in different media using different methodologies of inoculum production. Cells count reached $10^{8}$ cells/mL in $48 \mathrm{~h}$ using Czapeck medium. The same concentration was attained with the medium composed by CP extract only in $96 \mathrm{~h}$. The other medium and methodologies, Pellets and PDA, showed higher concentrations of viable cells after 144 and $120 \mathrm{~h}$, respectively.

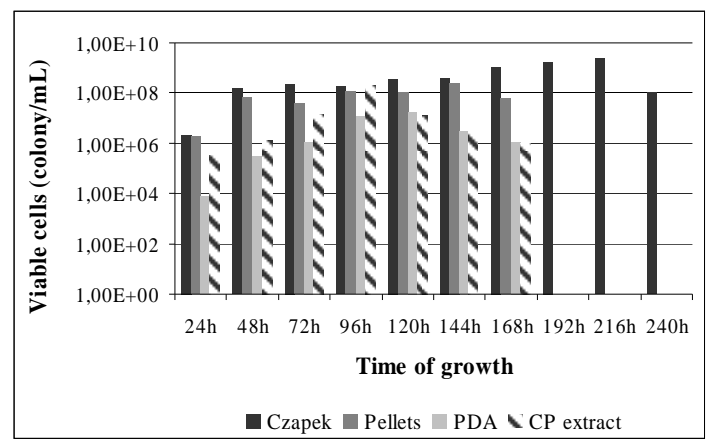

Figure 1 - Viables cells counting of inoculum produced using different methodologies of cultivation and media.

The development inoculum production of the strain $F$. moniliforme LPB 03 was successfully conducted using different media and methodologies. However, only Czapeck medium and $\mathrm{CP}$ extract showed better characteristics for the production of high concentrations of viable cells.

Since one of the objectives of this work was the use of agro-industrial wastes and/or byproducts, some complementary tests were performed with 
$\mathrm{CP}$ extract. In this case, some components of the Czapek medium (30 g/L sucrose, $3 \mathrm{~g} / \mathrm{L} \mathrm{NANO}_{3}, 1$ $\mathrm{g} / \mathrm{L} \mathrm{K}_{2} \mathrm{HPO}_{4}, 0.5 \mathrm{~g} / \mathrm{L} \mathrm{MgSO}_{4}, 0.5 \mathrm{KCl}$ and 0.01 $\mathrm{g} / \mathrm{L} \mathrm{FeSO}_{4}$ ) were added to $\mathrm{CP}$ extract so as to analyze the significant effect of each on inoculum production, according to a $2^{6-3}$ experimental design. The presence and the absence of each component were then examined.
According to Pareto diagram (Fig 2), sucrose was the most significant component at $\mathrm{p}$ level $<0.05$ $\left(\mathrm{R}^{2}=0,7049\right)$. Further studies were carried out for the production of inoculum using $\mathrm{CP}$ extract added of three concentrations of sucrose $(30,35$ and 40 $\mathrm{g} / \mathrm{L}$ ), with subsequent use in SSF for $\mathrm{GA}_{3}$ production. Higher cell concentrations were attained at $4^{\text {th }}$ day with all studied CP extracts (Fig 3).

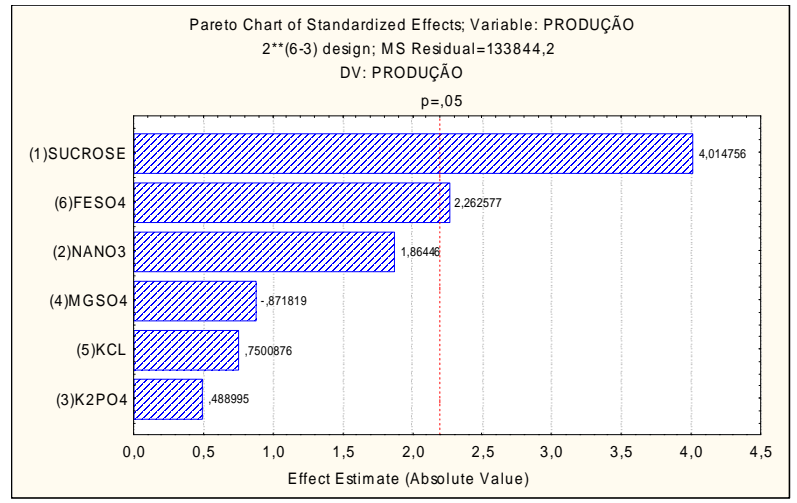

Figure 2 - Pareto chart of effects of the components adde to CP extrat medium

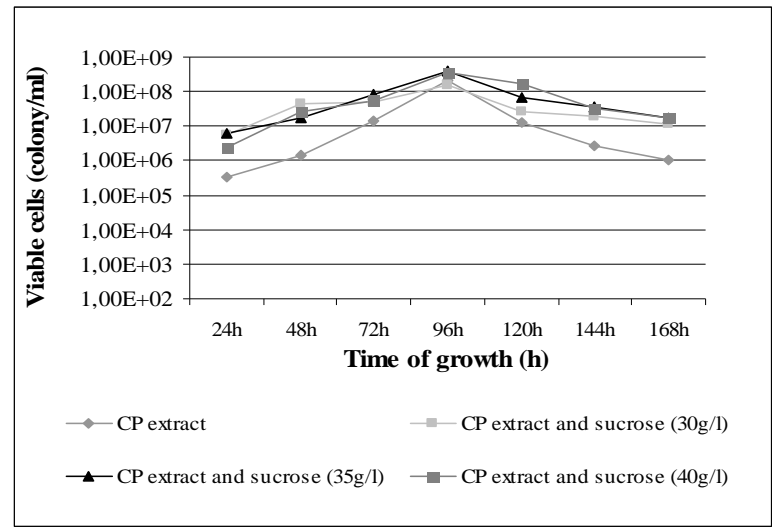

Figure 3 - Cells viability for inoculum produced in CP extracts.

Then, three inoculum rates $(10,15$ and $20 \% \mathrm{v} / \mathrm{w})$ were used. Higher concentrations of viable cells were obtained with $\mathrm{CP}$ extract added of $35 \mathrm{~g} / \mathrm{L}$ of sucrose using $15 \%$ of inoculum rate (data not shown).

The study of inoculum stability was carried out when the inoculum suspension was maintained under refrigeration $\left(4^{\circ} \mathrm{C}\right)$. It was observed a decrease in viability only after 5 days of storage (Fig 4). This fact allows the use of inoculum till 4 days.
Optimized conditions for inocolum production (15\% v/w, CP extract added of $35 \mathrm{~g} / \mathrm{L}$ sucrose) were used in a kinetic study of $\mathrm{GA}_{3}$ production with CP as substrate in solid-state fermentation by $F$. moniliforme LPB 03 . The best production was reached in the $3^{\text {th }}$ day of fermentation $(5.8 \mathrm{~g}$ of $\mathrm{GA}_{3} / \mathrm{kg}$ of $\mathrm{CP}$ ) (Fig 5). This production is comparable to the reported production of $\mathrm{GA}_{3}$ as it can be seen in Table 1. As an example, the production of $\mathrm{GA}_{3}$ obtained by Corona et al. (2005) reached $4.5-5 \mathrm{~g} / \mathrm{kg}$ dry basis using wheat meal and soluble starch. 


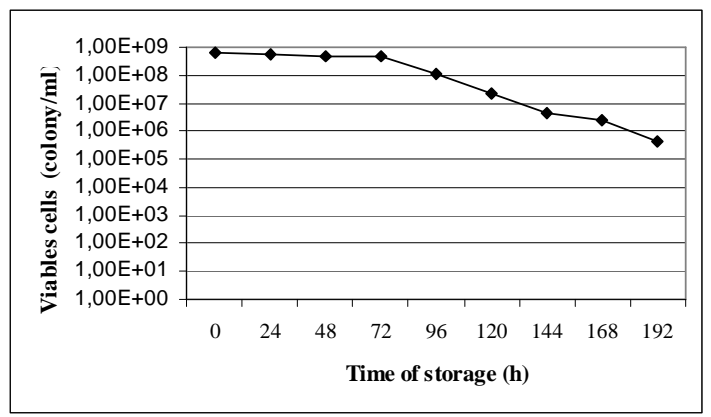

Figure 4 - Viability of inoculum of $F$. moniliforme LPB 03 produced using CP extract after storage stored under refrigeration.

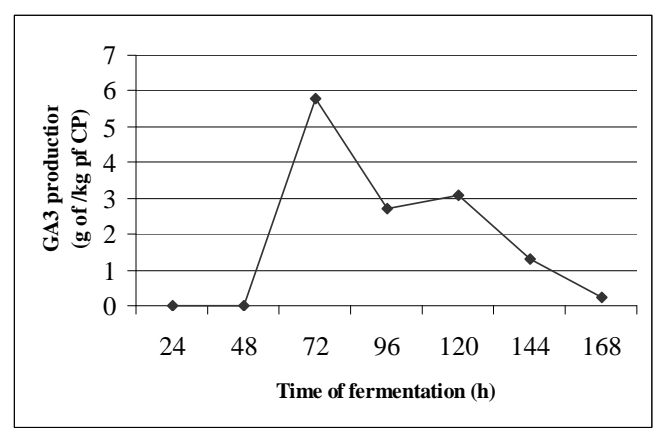

Figure 5 - Kinetic of $\mathrm{GA}_{3}$ production by SSF using $\mathrm{CP}$ as substrate by $F$. moniliforme LPB 03.

After this study, the same production of $\mathrm{GA}_{3}$ which was obtained using Czapek broth as a medium for inoculum growth was achieved. Besides, inoculum production time was decreased in 48h (from 144h with Czapek broth medium to 96h with $\mathrm{CP}$ extract). $\mathrm{GA}_{3}$ production in SSF $F$. moniliforme LPB 03 was also reduced in $24 \mathrm{~h}$, which represents an economically significant gain for the process.

\section{CONCLUSIONS}

The development of a new process passes through several steps of study and optimization. In this article, the screening of a productive strain and solid substrate/support were concluded. Citric pulp and $F$. moniliforme LPB 03 were chosen as substrate/support and strain, respectively, for $\mathrm{GA}_{3}$ production in SSF. Thus, the optimization of inoculum production was performed where CP extract added of sucrose was chosen for cells' cultivation.

Some patents that present the difficulty to produce 1-5 $\mathrm{g}$ of $\mathrm{GA}_{3} / \mathrm{L}$ are reported (Escamilla et al., 2000). In this work, a production $5.8 \mathrm{~g}$ of $\mathrm{GA}_{3} / \mathrm{kg}$ of $\mathrm{CP}$ was reached in 3 days even before any phisico-chemical optimization of the fermentation process. Moreover, $\mathrm{CP}$ has been proved to be a rather promising susbtrate to be used in the production of $\mathrm{GA}_{3}$ by SSF. Besides it is a subproduct of the juice industry which is produced in abundance. So the costs of this process of $\mathrm{GA}_{3}$ could be reduced, making it economically viable.

\section{RESUMO}

$\mathrm{O}$ ácido giberélico $\left(\mathrm{GA}_{3}\right)$ é um importante hormônio vegetal. A fermentação no estado sólido (FES) utiliza resíduos agro-industriais reduzindo os custos de produção. Neste trabalho a seleção de cepas (quatro de Gibberella fujikuoroi e uma de Fusarium moniliforme) e substratos (polpa cítrica, casca de soja, bagaço de cana, farelo de soja, bagaço de mandioca e casca de café) e o estudo da preparação do inóculo foram conduzidos para otimizar as condições de produção de $\mathrm{GA}_{3}$ por FES. Os ensaios foram realizados em frascos de erlenmeyer a $29^{\circ} \mathrm{C}$, com umidade inicial de 75 $80 \%$. Diferentes meios para a produção do inóculo foram testados em relação à viabilidade das células 
e produção de $\mathrm{GA}_{3}$ por FES. F. moniliforme LPB03 e polpa cítrica foram escolhidos. O melhor meio para a produção de inóculo foi o extrato de polpa cítrica. A produção por FES alcançou $5.8 \mathrm{~g}$ de $\mathrm{GA}_{3} / \mathrm{kg}$ de polpa cítrica após 3 dias de fermentação.

\section{AKNOWLEDGEMENTS}

The financial resources for the conduction of this study were supported by the project BioAgroPar financed by FINEP, SETI/PR, and Fundação Araucária/PR; and by CNPq/Brazil.

\section{REFERENCES}

Bandelier, S., Renaud, R., Durand, A. (1997), Production of gibeberellic acid by fed-batch solid state fermentation in as aseptic pilot-scale reactor. Process Biochemistry, 32, 141-45

Banwart, G. J. (1982), Microbiologia básica de los alimentos. Barcelona: Belaterra, p. 464

Castro, L. B. B. N., Oliveira, L. A., Moreira, R. F., Murta, R. M. (2008), Bagaço de cana-de-açúcar para alimentação de ruminantes. PUBVET, 2, 30.

Corona, A, Sanchez, D, Agostin, E. (2005), Effect of water activity on gibberellic acid production by Gibberella fujikuroi under solid-state fermentation conditions. Process Biochemistry, 40, 2655-58.

Escamilla, E. M., Dendooven, L., Magaña, I. P, Parra, R., De La Torre, M. (2000), Optimization of gibberellic acid production by immobilized Gibberella fujikuroi mycelium in fluidized bioreactors. Journal of Biotechnology, 76, 147-55.

Holbrook, A., Edge, W., Bailey, F. (1961), Spectrophotometric method for determination of gibberellic acid. Adv Chem Ser., 28, 159-67.

Hollmann, D., Switalski, J., Geipel, S., Onken, U. (1995), Extractive fermentation of Gibberellic acid by Gibberella fujikuroi. J Ferment Bioeng., 79, 594-600.

Holme, T., Zacharia, B. (1965), Gibberellic Acid Formation In Continuous Culture. Biotechnol Bioeng., 7, 405-12.

Jefferys, E. G. (1970), The gibberellin fermentation. Adv Appl Biol., 13, 283-316.

Kagawa, A. (1995), ed. Standard table of food composition in Japan. Tokyo: University of Nutrition for women, 104-105.

Kumar, P. K. R, Lonsane, B. K. (1989), Microbial Production of Gibberellins: state of the art. Advances in Applied Microbiology, 34, 29-139.

Linnemannstons, P., Schulte, J., Prado, M. M, Proctor, R. H, Avalos, J., Tudzynski, B. (2002), The polyketide synthase gene pks4 from Gibberella fujikuroi encodes a key enzyme in the biosynthesis of the red pigment bikaverin. Fungal Genet Biol., 37, 134-148.

Machado, C. M. M, Oliveira, B. H, Pandey, A., Soccol, C. R. (2001), Coffee husk as substrate for the production of gibberellic acid by fermentation. In: Book on Coffee Biotechnology and Quality, Sera T., Soccol C. R, Pandey A. and Roussos S. (eds), Kluwer Academic Publishers, Dorcrecht, pp 401-8.

Machado, C. M. M, Soccol, C. R and Pandey, A. (2002), Gibberellic acid production by solid state fermentation in coffee husk. Applied Biochemistry and Biotechnology, 102, 179-192.

Machado, C. M. M, Soccol, C. R, Oliveira, B. H, Pandey, A. (2004), Physical And Nutritional Factors Influencing Gibberelic Acid Production By SolidState Fermentation Using Coffee Husk And Cassava Bagasse. In: Rainer Jonas, Ashok Pandey, Guenter Tharun. (Org.). Biotecnological Adavances And Applications In Bioconversion Of Renewable Raw Materials. 1 Ed. Braunscheweig: Doehring Druck, pp 157-162.

O’Donnell, K., Cigelnik, E., Nirenberg, H. I. (1998), Molecular systematics and phylogeography of the Gibberella fujikuroi species complex. Mycologia, 90, 465-93.

Pandey, A., Soccol, C. R, Rodriguez-Leon, J. A, Nigan, P. (eds) (2001), Solid State Fermentation in Biotechnology - Fundamentals and Applications. Asiatech Publishers Inc., New Delhi, p 221.

Passos, I. R. S, Matos, G. V. C, Meletti, L. M. M, Scott, M. D. S, Bernacci, L. C, Vieira, M. A. R. (2004), Utilização do ácido giberélico para a quebra de dormência de sementes de Passiflora nitida Kunth germinadas in vitro. Revista Brasileira de Fruticultura, 26, 380-81.

Rodrigues, C. (2006), Desenvolvimento de Bioprocesso para Produção de Ácido Cítrico por Fermentação no Estado Sólido Utilizando Polpa Cítrica, Dissertação de Mestrado, Universidade Federal do Paraná (UFPR), Curitiba, Brasil.

Shukla, R., Chand, S., Srivastava, A. K. (2005), Batch kinetics and modeling of gibberellic acid production by Gibberella fujikuroi. Enzyme and Microbial Technology, 36, 492-7.

Soccol, C. R, Vandenberghe, L. P. S. (2003), Overview of applied solid-state fermentation in Brazil. Biochemical Engineering Journal, 13, 205-18.

Soccol, C. R, Vandenberghe, L. P. S, Rodrigues, C., Pandey, A. (2006), New Perspectives for Citric Acid Production and Application. Food Technol Biotechnol, 44, 141-9.

Tudzynski, B. (1999), Biosynthesis of gibberellins in Gibberella fujikuroi: biomolecular aspects. Applied Microbiology and Biotechnology, 52, 298-310.

Vandenberghe, L. P. S., Soccol, C. R., Pandey, A., Lebeault, L-M. (2000), Solid-state fermentation for the synthesis of citric acid by Aspergillus niger. Biores. Technol., 74, 175-178. 